\title{
Pola Pewarisan Karakter Umur Tanaman Sorgum (Sorghum bicolor(L.) Moench)
}

\author{
Anas* dan Iman Lukmanul Hakim \\ Laboratorium Pemuliaan Tanaman Fakultas Pertanian Universitas Padjadjaran \\ Jl. Raya Bandung Sumedang Km. 21 Jatinangor 40600 \\ *Alamat korespondensi: anas@unpad.ac.id
}

\begin{abstract}
Inheritance Pattern of Maturity Character of Sorghum (Sorghum bicolor(L.) Moench)

Information on the inheritance pattern for the maturity characters in sorghum (Sorghum bicolor [L.] Moench) is important for plant breeding program of early maturity sorghum. Objective of this experiment was to evaluate genetic control of days to flowering and anthesis. Three series of crossing Unpad $1.1 \times 2.24-1$, Unpad $1.1 \times 2.24-3$ and BSS x 2.24 were grown in field experiment at Ciparanje experimental station, Faculty of Agriculture, Universitas Padjadjaran, Jatinangor, Sumedang, West Java, from July to December 2014. As much 1046 F2 seeds were planted in row plot. Normality of data was analyzed by Kolmogorov-Smirnov test and inheritance pattern of data was analyzed by Chi Square test. The result showed that the distribution of days to flowering and anthesis was not normal distributed. Inheritance pattern of days to flowering and anthesis of Unpad 1.1 x 2.24-1, Unpad $1.1 \times 2.24-3$ and BSS x 2.24 tended to resemble Mendel's inheritance pattern of 12:3:1 (epistasy dominant), and 13:3 (dominant-recessive epistasy).
\end{abstract}

Keywords : Sorghum, Inheritance pattern, Maturity, Chi-square

\begin{abstract}
ABSTRAK
Informasi mengenai pola pewarisan karakter-karakter umur tanaman sorgum sangat penting dalam program pemuliaan tanaman sorgum berumur genjah. Penelitian ini bertujuan untuk mengevaluasi kontrol genetik karakter umur berbunga dan umur anthesis. Tiga seri persilangan dari Unpad $1.1 \mathrm{x}$ 2.24-1, Unpad $1.1 \times 2.24-3$ dan BSS x 2.24 ditanam di kebun percobaan Ciparanje Fakultas Pertanian Universitas Padjadjaran, Kecamatan Jatinangor, Kabupaten Sumedang, Jawa Barat. Percobaan dilaksanakan dari bulan Juli sampai Desember 2014. Sebanyak 1046 benih $F_{2}$ ditanam dalam petak baris. Normalitas data dianalis dengan uji Kolmogorov-Smirnov dan pola pewarisan data dianalisis dengan uji Khi Kuadrat. Hasil penelitian menunjukkan sebaran fenotip karakter umur berbunga dan umur anthesis tidak berdistribusi normal. Pola pewarisan karakter umur berbunga dan umur anthesis pada genotipe hasil persilangan Unpad 1.1 x 2.24-1, Unpad 1.1 x 2.243 dan BSS x 2.24 cenderung menyerupai pola pewarisan nisbah Mendel 12:3:1 (epistasis dominan) dan 13:3 (epistasis dominan-resesif).

Kata Kunci: Sorgum, Pola pewarisan, Umur tanaman, Khi Kuadrat
\end{abstract}

\section{PENDAHULUAN}

Tanaman sorgum (Sorghum bicolor [L.] Moench) mempunyai potensi yang baik untuk dikembangkan di Indonesia. Pemanfaatan tanaman sorgum sebagai tanaman pangan menduduki urutan kelima setelah gandum, padi, jagung, dan barli (Sleper \& Poehlman, 2006). Seluruh bagian tanaman sorgum bisa dimanfaatkan baik sebagai pangan, pakan atau sebagai bahan baku industri.

Salah satu usaha perbaikan tanaman dalam pemuliaan tanaman yaitu merakit tanaman sorgum 
yang berumur genjah. Identifikasi gen yang mengendalikan karakter umur tanaman sangat penting dalam merakit tanaman sorgum berumur genjah. Pada mulanya Quinby (1974) menyatakan bahwa terdapat 4 pasang gen yang mengontrol sifat umur tanaman, yaitu Ma1-Ma4. Selanjutnya Rooney \& Aydin (1999) menemukan 2 pasang gen lagi yang mengontrol sifat umur tanaman yaitu Ma5 dan Ma6. Oleh karena itu terdapat 6 pasang gen (Ma1-Ma6) yang mengontrol sifat umur tanaman sorgum (Sleper \& Poehlman, 2006).

Yano et al. (2001) melaporkan bahwa terdapat 14 gen yang mengendalikan karakter umur berbunga pada tanaman padi yang dikendalikan secara kuantitatif. Sama halnya pada tanaman jagung bahwa umur berbunga dikendalikan oleh banyak gen (Salvi, 2010). Menurut Gelonch et al. (2011) pada tanaman gandum umur berbunga dan umur anthesis dikendalikan secara poligenik. Lain halnya pada tanaman kedelai, karakter umur berbunga dan umur panen dikendalikan oleh gen yang berbeda. Umur berbunga pada tanaman kedelai dikendalikan oleh banyak gen sedangkan umur panen dikendalikan oleh sedikit gen (Nugroho dkk., 2013; Sa'diyah, 2013). Beragamnya gen pengendali yang mengatur karakter-karakter umur tanaman akan menjadi landasan untuk mengevaluasi dan mengidentifikasi bentuk sebaran gen dan pola pewarisan karakter-karakter umur tanaman sorgum.

Hal lainnya yang berpengaruh dalam kontrol genetik umur pada tanaman sorgum adalah pengaruh faktor lingkungan. Menurut Sleeper \& Poehlman (2006) karakter umur tanaman sorgum dipengaruhi oleh lingkungan yaitu, panjang hari dan suhu. Sebelumnya penelitian karakter umur tanaman sorgum dilakukan di daerah subtropis baik itu menurut Quinby (1974) ataupun Rooney \& Aydin (1999), yang mana panjang harinya lebih dari 12 jam. Sorgum termasuk tanaman berhari pendek yang membutuhkan panjang hari kurang dari 12 jam untuk berbunga (House 1985). Menurut Anas \& Yoshida (2004a) umur berbunga tanaman sorgum mempunyai tingkat heritabilitas yang rendah. Oleh karena itu perlu adanya identifikasi gen yang mengendalikan karakter umur tanaman sorgum di daerah tropis khususnya di Indonesia.

Gen yang mengatur karakter suatu tanaman dikendalikan secara simpelgenik atau poligenik. Simpelgenik berarti karakter tersebut dikendalikan oleh sedikit gen serta pengaruh gen terhadap ekspresi karakter tersebut tinggi, sedangkan poligenik dikendalikan oleh banyak gen serta pengaruh dari gen-gen tersebut kecil terhadap ekspresi suatu karakter (Sleeper \& Poehlman, 2006). Karakter yang dikendalikan oleh sedikit gen akan memberikan suatu pola segregrasi yang mengikuti hukum Mendel dan modifikasinya. Berbeda dengan karakter yang dikendalikan oleh banyak gen, karena pengaruh dari masing-masing gen kecil terhadap suatu karakter maka pewarisannya tidak sederhana dan tidak mengikuti pola pewarisan Hukum Mendel (Trustinah, 1997).

Karakter tanaman yang dipengaruhi banyak gen dapat diketahui melalui sebaran frekuensinya yang berdistribusi normal atau continue, sedangkan apabila suatu karakter tersebut dikendalikan oleh simpelgenik maka sebaran frekuensinya tidak berdistribusi normal atau discontinue (Nugroho dkk., 2013). Sebaran frekuensi tersebut akan menentukan suatu karakter dikendalikan secara kuantitatif (banyak gen) atau kualitatif (sedikit gen) (Allard, 1999). Pengendali karakter umur tanaman sorgum, baik itu dikendalikan secara kuantitatif ataupun kualitatif akan mempermudah dalam program pemuliaan tanaman sorgum berumur genjah.

Tiga persilangan genotip sorgum Unpad $1.1 \mathrm{x}$ 2.24-1, Unpad 1.1 x 2.24-3 dan BSS x 2.24.dilakukan untuk mendapatkan karakter sorgum yang berumur genjah. Tetua yang digunakan adalah Unpad 1.1 mempunyai hasil panen yang tinggi akan tetapi umur berbunganya yang dalam, sedangkan Unpad 2.24 mempunyai umur berbunga yang cepat akan tetapi hasil panennya yang rendah. Tetua BSS mempunyai biomass dan hasil panen yang tinggi akan tetapi umur berbunganya yang dalam. Tujuan dari penelitian ini adalah untuk mengetahui sebaran gen dan pola segregasi karakter-karakter umur tanaman sorgum generasi $F_{2}$ dari hasil persilangan Unpad 1.1 x 2.24-1, Unpad 1.1 x 2.24-3 and BSS $\mathrm{x}$ 2.24 .

\section{BAHAN DAN METODE}

Percobaan dilakukan di Kebun Percobaan Ciparanje Fakultas Pertanian Universitas Padjadjaran, Kecamatan Jatinangor, Kabupaten Sumedang, Jawa Barat. Percobaan dilaksanakan dari bulan Juli sampai Desember 2014. Jumlah benih sorgum $\mathrm{F}_{2}$ yang digunakan yaitu, hasil dari persilangan Unpad 1.1 x 2.24-1 (A1) sebanyak 463 biji, hasil dari persilangan Unpad 1.1 x 2.24-3 (A3) sebanyak 64 biji dan hasil dari persilangan BSS $x$ Unpad 2.24 (B1) sebanyak 519 biji.

Pengolahan lahan dilakukan 2 minggu sebelum tanam bersamaan dengan pengaplikasian 
pupuk kandang dosis 5 ton/ha. Benih A1, A3 dan B1 ditanam secara bersamaan dalam 8 petak baris dengan ukuran $6 \times 4,4 \mathrm{~m}$, jarak antar plot $1 \mathrm{~m}$ dan jarak tanam 75 x $15 \mathrm{~cm}$. Pemupukkan bersamaan dengan penanaman. Dosis pupuk yang digunakan yaitu, pupuk urea 200kg/ha, $\mathrm{SP}_{36} 125 \mathrm{~kg} / \mathrm{ha}$ dan $\mathrm{KCl}$ $50 \mathrm{~kg} / \mathrm{ha}$. Aplikasi pupuk $\mathrm{SP}_{36}$ dan $\mathrm{KCl}$ bersamaan diberikan pada lubang yang ditugal di samping tanaman sorgum sedangkan pemupukkan urea aplikasinya tidak dicampur dengan $\mathrm{SP}_{36}$ atau $\mathrm{KCl}$. Pupuk urea diberikan 2 kali. Pertama, 1/3 dosis diberikan bersamaan dengan penanaman. Kedua 2/3 dosis diberikan sebulan setelah penanaman.

Pengendalian gulma yaitu dengan pengaplikasian herbisida glifosat $486 \mathrm{~g} / \mathrm{l}$ pada saat pengolahan lahan. Pengendalian hama menggunakan insektisida berbahan aktif profenofos dengan konsentrasi $2 \mathrm{ml} / \mathrm{l}$. Pengendalian jamur dengan fungisida dan apabila yang menyerang tanaman adalah virus maka tanaman dicabut kemudian dibakar.

Data yang diamati berdasarkan tanaman tunggal pada seluruh individu tanaman. Karakter yang diamati meliputi umur berbunga, umur anthesis dan umur panen.

Metode percobaan yang digunakan adalah tanpa rancangan karena benih masih bersegregasi (Baihaki, 2000). Uji normalitas menggunakan uji Kormogorov-Smirnov dengan bantuan SPSS Versi 22. Uji pola segregasi menggunakan uji Khi Kuadrat.

Kesesuaian segregasi karakter-karakter umur tanaman sorgum dengan tipe segregasi yang diharapkan diuji dengan Khi Kuadrat (Gomez \& Gomez, 1995)

1) Dua kelas

$$
x^{2}=\frac{\left(\left\|n_{1}-E_{1}\right\|-0,5\right)^{2}}{E_{1}}+\frac{\left(\left\|n_{2}-E_{2}\right\|-0,5\right)^{2}}{E_{2}}
$$

2) Lebih dari dua kelas

$$
x^{2}=\sum_{j=1}^{e} \frac{\left(O_{i}-E_{i}\right)^{2}}{E i}
$$

Keterangan:

$$
\begin{aligned}
& \mathrm{Oj}=\text { jumlah pengamatan dalam } \\
& \text { kelas/kelompok ke-i } \\
& \begin{array}{ll}
\mathrm{Ej} \quad=\text { jumlah pengamatan yang } \\
\text { diharapan dalam kelas/kelompok ke-i }
\end{array} \\
& \mathrm{j} \quad=1,2,3, \ldots
\end{aligned}
$$

Pendugaaan gen pengendali untuk karakter yang dikendalikan sedikit gen maka populasi $\mathrm{F}_{2}$ akan dicocokkan terhadap beberapa nisbah, tergantung dari bentuk grafik yang diperoleh (Komariah dkk.,
2003). Berikut pencocokan bentuk-bentuk grafik terhadap nisbah Mendel:

- $\quad$ Bentuk grafik dua puncak, maka kemungkinan nisbah yang terjadi adalah 3:1 (1 gen dominan penuh), 9:7 (2 gen epistasis resesif duplikat), 13:3 (2 gen epistasis dominan resesif), 15:1 (2 gen epistasis dominan duplikat).

- Bentuk grafik tiga puncak, maka kemungkinan nisbah adalah 1:2:1 (1 gen dominan tidak sempurna), 9:3:4 (2 gen epistasis resesif), 9:6:1 (2 gen dengan efek kumulatif), 12:3:1 (2 gen epistasis dominan).

- Bentuk grafik empat puncak, maka kemungkinan nisbah fenotipe yang terjadi adalah 9:3:3:1 (2 gen dominan penuh), atau 6:3:3:4 (1 pasang gen dominan sempurna dan 1 pasang gen dominan sebagian).

Jika t hitung lebih kecil dari t tabel maka data sesuai dengan nisbah Mendel yang diuji $\chi^{2}$ hitung $<\chi^{2}$ tabel atau $\mathrm{H}_{0}$ diterima. Jika $\mathrm{t}$ hitung lebih besar dari $t$ tabel maka data tersebut tidak sesuai dengan nisbah Mendel yang diuji, $\chi^{2}$ hitung $>\chi^{2}$ Tabel atau $\mathrm{H}_{0}$ ditolak.

Penentuan jumlah sampel pada populasi $\mathrm{F}_{2}$ menggunakan rumus Muller (1923) dan Sedcole (1977) dalam Francis et al. (2012) sebagai berikut:

$$
\mathrm{N}=\frac{\log e(1-p)}{\log e(1-f)}
$$

Keterangan :

$$
\begin{aligned}
& \mathrm{N} \quad=\text { Jumlah sampel minimal } \\
& \mathrm{P} \quad=\text { Probabilitas keberhasilan }(99 \%, \\
& 95 \%, 90 \%) \\
& \mathrm{F} \quad=\text { Frekuensi alel }
\end{aligned}
$$

Suatu individu $\mathrm{F}_{2}$ akan memiliki kemungkinan menjadi homozigot pada satu gen ialah 0,25. Diasumsikan bahwa untuk sifat kualitatif terdiri dari 2 gen pengendali, maka minimal populasi untuk kemungkinan adanya individu yang homozigot di $\mathrm{F}_{2}$ adalah $\mathrm{N}=\log _{\mathrm{e}}(1-\mathrm{P}) / \log _{\mathrm{e}}(1-\mathrm{f})=$ $\log _{\mathrm{e}}(1-0.99) / \log _{\mathrm{e}}\left(1-(0.25)^{2}\right)=71.86$ atau 72 tanaman.

\section{HASIL DAN PEMBAHASAN}

Hasil uji normalitas Kolmogorov-Smirnov dengan bantuan SPSS versi 22 pada karakter umur berbunga dan umur anthesis genotip A1, genotip A3 dan genotip B1 menunjukkan distribusi data yang tidak normal. Data umur panen tidak dianalisis karena kehilangan data mencapai 50\% akibat hama burung. Nilai signifikansi 0.000 (Tabel 1) 
menunjukkan nilai data yang sangat kecil terhadap nilai kepercayaan 95\%.

Bentuk grafik karakter umur berbunga dan umur anthesis mempunyai kecenderungan lebih condong ke arah kiri dengan beberapa puncak, tidak cocok dengan garis kurva data yang berdistribusi normal (Gambar 1, Gambar 2). Padahal pada penelitian sebelumnya pada tanaman jagung (Salvi dkk., 2010), padi (Yano et al., 2001), gandum
(Gelonch et al., 2011) dan kacang kedelai (Nugroho dkk., 2013) dan (Sa'diyah dkk., 2013), karakterkarakter tersebut berdistribusi normal. Karakter dengan sebaran data berdistribusi normal menunjukkkan bahwa karakter tersebut dikendalikan secara poligenik. Menurut Anas \& Yoshida (2004b), karakter yang dikendalikan secara kuantitatif akan mempunyai tingkat heritabiltas yang rendah.

Tabel 1: Hasil uji normalitas data.

\begin{tabular}{lll}
\hline Karakter & Genotipe & Keterangan \\
\hline \hline Umur Berbunga & $\mathrm{A}^{*}$ & Tidak Normal \\
& $\mathrm{A}^{*}$ & Tidak Normal \\
& $\mathrm{B}^{*}$ & Tidak Normal \\
\hline Umur Anthesis & $\mathrm{A}^{*}$ & Tidak Normal \\
& $\mathrm{A}^{*}$ & Tidak Normal \\
& $\mathrm{B} 1^{*}$ & Tidak Normal \\
\hline
\end{tabular}

Keterangan: ${ }^{*}$ dan tn) nyata dan tidak nyata pada taraf $\alpha 5 \%$.

Ada beberapa faktor yang menyebabkan umur berbunga dan umur anthesis tidak berdistribusi normal dan bentuk grafik cenderung berkumpul di sebelah kiri. Menurut Allard (1999) bentuk grafik condong ke arah kiri adalah hasil dari bentuk grafik dengan adanya pengaruh dominansi
Hal tersebut berdasarkan asumsi bahwa, jika semua pasang gen tidak mempunyai pengaruh frekuensi alel yang sama atau $\mathrm{p} \neq \mathrm{q}$ maka distribusinya akan cenderung menyerupai bentuk distribusi yang dikendalikan oleh sedikit gen, begitu juga bila terdapat pautan.
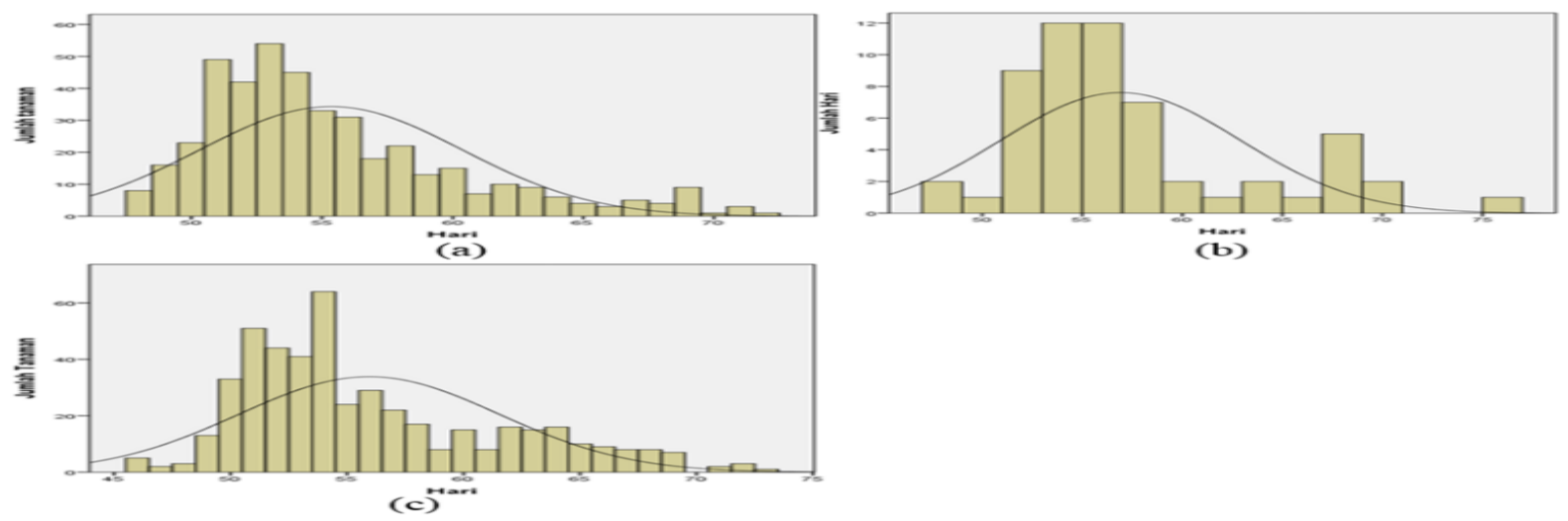

Gambar 1. Perbandingan grafik umur berbunga dengan kurva distribusi normal pada tiga populasi $F_{2}$ : (a) A1, (b) A3, (c) B1.

Menurut Sleeper \& Poehlman (2006) waktu pembungaan dipengaruhi oleh suhu dan panjang hari. Suhu udara selama percobaan berkisar antara $22,6-23,7^{\circ} \mathrm{C}$. Menurut FAO (2015) sorgum akan lebih lebih cepat berbunga pada suhu $22-26^{\circ} \mathrm{C}$ dibandingkan dengan suhu $17-20^{\circ} \mathrm{C}$ sehingga bentuk grafik cenderung berkumpul di sebelah kiri.
Semakin banyak bentuk dominan pada gen pengendali pembungaan, Ma1-Ma6, maka pembungaan akan semakin lama pada panjang hari lebih dari 12 jam dan bentuk grafik akan condong kearah kanan (Quinby, 1974). Sorgum termasuk tanaman berhari pendek yang membutuhkan panjang hari kurang dari 12 jam untuk berbunga (House, 1985). Hal tersebut yang menjadi dugaan 
bahwa bentuk grafik lebih condong ke arah kiri meskipun terdapat tanaman yang mempunyai gen dominan, karena penelitian dilakukan di daerah
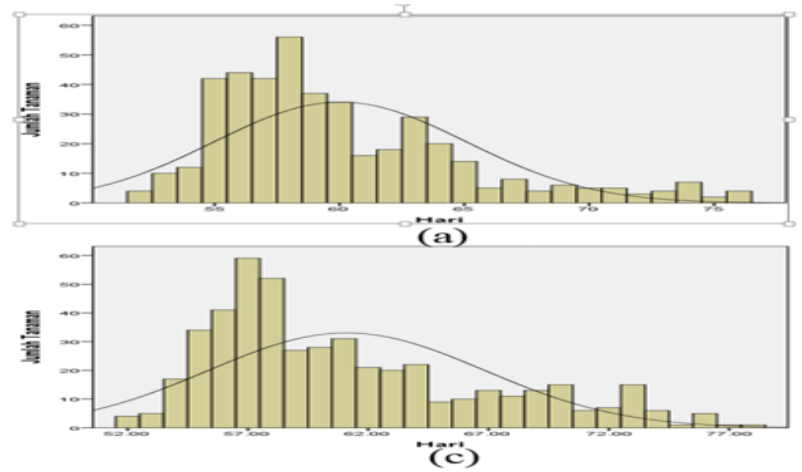

tropis yang mempunyai panjang hari kurang dari 12 jam.

Gambar 2. Perbandingan grafik umur anthesis dengan kurva distribusi normal pada tiga populasi $F_{2}$ : (a) A1, (b) A3, (c) B1.

Tabel 2. Hasil uji Khi Kuadrat umur berbunga.

\begin{tabular}{|c|c|c|c|c|}
\hline \multirow{2}{*}{$\begin{array}{l}\text { Nisbah Mendel dan } \\
\text { Modifikasinya }\end{array}$} & \multicolumn{3}{|c|}{$\chi^{2}$ Hitung Umur Berbunga } & \multirow{2}{*}{$\chi^{2}(0,05)$} \\
\hline & A1 & A3 & B1 & \\
\hline $3: 1$ & $33,78^{*}$ & $0,70^{\text {tn }}$ & $5,95^{*}$ & 3,84 \\
\hline $9: 7$ & $166,93^{*}$ & $11,03^{*}$ & $107,30^{*}$ & \\
\hline 13:3 & $10,4^{*}$ & $0,08^{\mathrm{tn}}$ & $0,44^{\mathrm{tn}}$ & \\
\hline $15: 1$ & $30,08^{*}$ & $18,86^{*}$ & $151,54^{*}$ & \\
\hline $9: 6: 1$ & $57,38^{*}$ & $12,09^{*}$ & $179,83^{*}$ & 5,99 \\
\hline $12: 3: 1$ & $1,46^{\text {tn }}$ & $1,97^{\mathrm{tn}}$ & $161,45^{*}$ & \\
\hline $9: 3: 4$ & $91,67^{*}$ & - & - & \\
\hline 9:3:3:1 & $61,25^{*}$ & $6,09^{\mathrm{tn}}$ & $114,13^{*}$ & 7,81 \\
\hline \multicolumn{5}{|l|}{$\begin{array}{c}\text { Pewarisan Poligenik } \\
2 \text { Pasang Gen }\end{array}$} \\
\hline $1: 4: 6: 4: 1$ & $629,25^{*}$ & $13,85^{*}$ & $288,23^{*}$ & 9,49 \\
\hline \multicolumn{5}{|l|}{$\begin{array}{c}\text { Pewarisan Poligenik } \\
3 \text { Pasang Gen }\end{array}$} \\
\hline $1: 6: 15: 20: 15: 6: 1$ & $186,12^{*}$ & - & $110,87^{*}$ & 14,07 \\
\hline \multicolumn{5}{|l|}{$\begin{array}{c}\text { Pewarisan Poligenik } \\
4 \text { pasang Gen }\end{array}$} \\
\hline 1:8:28:56:70:56:28:8:1 & $832,43^{*}$ & - & $405,04^{*}$ & 16,92 \\
\hline
\end{tabular}

Keterangan: " dan tn) nyata dan tidak nyata pada taraf $\alpha 5 \%$

Sebelumnya dijelaskan bahwa meskipun gen pengendali umur berbunga pada sorgum ada 6 Ma1-Ma6 (Sleeper \& Poehlman, 2006), akan tetapi menurut Murphy et al. (2011) gen Ma1 adalah gen

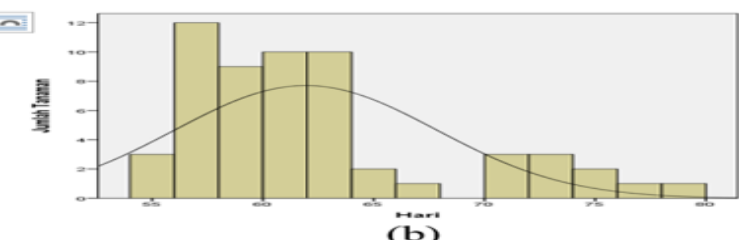

(b) 
dominan di Ma1 akan memperlambat pembungaan. Oleh karena itu meskipun gen yang mengendalikan pembungaan 6 pasang akan tetapi yang paling berpengaruh adalah Ma1 maka seolah-olah bentuk sebaran fenotip menyerupai distribusi fenotip yang dikendalikan oleh sedikit gen. Pengaruh dari interaksi gen secara epistasis juga akan menyebabkan bentuk kurva condong ke arah kiri dan menyebabkan kurva tidak berdistribusi normal (House, 1985). Data yang tidak berdistribusi normal akan dilanjutkan dengan uji Khi Kuadrat untuk menguji kesesuaiannya dengan beberapa nisbah Mendel dan modifikasinya. Pencocokkan kemiripan bentuk grafik pengamatan dengan nisbah Mendel bertujuan agar memudahkan dalam proses seleksi tanaman sorgum.

Hasil uji Khi Kuadrat karakter umur berbunga pada genotipe A1 menunjukkan data pengamatan sesuai dengan nisbah. Mendel 12:3:1 (dominan epistasis). Nilai Khi kuadrat dengan nisbah Mendel 12:3:1 yaitu 1,46, lebih kecil dibandingkan dengan nilai $\chi^{2}$ tabel 3.81 (Tabel 2). Menurut Karmana \& Rostini (2008) dominan epistasis adalah dominan penuh dari dua pasangan gen mempengaruhi sifat yang sama, tetapi alil dominan pada satu lokus menghasilkan fenotipe tertentu tidak tergantung dari gen pada lokus lainnya, dominan atau resesif. Jadi gen tadi epistasis terhadap lainnya atau menutupi efek gen lainnya.

Nisbah Mendel yang sesuai dengan bentuk grafik pada umur berbunga Genotipe A3 yaitu 13:3 (epistasis dominan-resesif) (Tabel 2). Hasil $\chi^{2}$ hitung yang lebih kecil dari $\chi^{2}$ tabel menunjukkan bahwa hasil uji Khi Kuadrat sesuai dengan nisbah Mendel yang diujikan. Selain nisbah Mendel 13:3 terdapat beberapa nisbah Mendel lain yang sesuai dengan hasil uji Khi Kuadrat umur berbunga A3. Hasil tersebut ditunjukkan dengan nilai $\chi^{2}$ hitung lebih kecil dari $\chi^{2}$ tabel. Akan tetapi nilai Khi Kuadrat nisbah Mendel 13:3 (epistasis dominan-resesif) adalah 0,08 lebih kecil dibandingkan dengan nilai khi kuadrat nisbah Mendel lain.

Hasil uji Khi Kuadrat umur berbunga pada genotipe B1 menunjukkan kecocokkan dengan nisbah Mendel 13:3 (epistasis dominan-resesif). Nilai $\chi^{2}$ hitung yang lebih kecil dengan $\chi^{2}$ tabel yaitu 0,44 $<3,84$, menunjukkan bahwa nisbah tersebut sesuai dengan bentuk grafik hasil percobaan. Epistasis dominan - resesif terjadi apabila gen dominan dari pasangan gen I epistatis terhadap pasangan gen II yang bukan alelnya, sementara gen resesif dari pasangan gen II ini juga epistatis terhadap pasangan gen I (Susanto, 2011).

Tabel 3: Hasil uji Khi Kuadrat umur anthesis.

\begin{tabular}{|c|c|c|c|c|}
\hline \multirow{2}{*}{$\begin{array}{l}\text { Nisbah Mendel dan } \\
\text { Modifikannya }\end{array}$} & \multicolumn{3}{|c|}{$\chi^{2}$ Hitung Umur Anthesis } & \multirow[t]{2}{*}{$\chi^{2}(0.05)$} \\
\hline & A1 & $\mathrm{A} 3$ & B1 & \\
\hline $3: 1$ & $44,91^{*}$ & $3,09^{\text {tn }}$ & $2,2^{\mathrm{tn}}$ & 3,84 \\
\hline $9: 7$ & $184,95^{*}$ & $16,98^{*}$ & $90,72^{*}$ & \\
\hline $13: 3$ & $16,90^{*}$ & $0,55^{\mathrm{tn}}$ & $2,96^{\mathrm{tn}}$ & \\
\hline $15: 1$ & $16,74^{*}$ & $7,29^{*}$ & $196,5^{*}$ & \\
\hline $9: 6: 1$ & $57,45^{*}$ & $8,9^{*}$ & $109,21^{*}$ & 5,99 \\
\hline $12: 3: 1$ & $0,89^{\mathrm{tn}}$ & $21,5^{*}$ & $6,86^{*}$ & \\
\hline 9:3:4 & - & - & $102,42^{*}$ & \\
\hline $9: 3: 3: 1$ & $46,98^{*}$ & $12,83^{*}$ & $29,10^{*}$ & 7,81 \\
\hline \multicolumn{5}{|l|}{$\begin{array}{c}\text { Pewarisan Poligenik } \\
2 \text { Pasang Gen }\end{array}$} \\
\hline $1: 4: 6: 4: 1$ & $704,60^{*}$ & $191,18^{*}$ & - & 9,49 \\
\hline \multicolumn{5}{|l|}{$\begin{array}{c}\text { Pewarisan Poligenik } \\
3 \text { Pasang Gen }\end{array}$} \\
\hline $1: 6: 15: 20: 15: 6: 1$ & $133,22^{*}$ & - & $1343,75^{*}$ & 14,07 \\
\hline \multicolumn{5}{|l|}{$\begin{array}{c}\text { Pewarisan Poligenik } \\
4 \text { pasang Gen }\end{array}$} \\
\hline $1: 8: 28: 56: 70: 56: 28: 8: 1$ & $433,01^{*}$ & - & $516,55^{*}$ & 16,92 \\
\hline
\end{tabular}

Keterangan: ${ }^{*}$ dan tn) nyata dan tidak nyata pada taraf $\alpha 5 \%$. 
Hasil uji Khi Kuadrat kecocokkan nisbah Mendel pada karakter umur anthesis genotipe A1 dan A3 sama dengan umur berbunganya. 12:3:1 (dominan epistasis) untuk A1 dan 13:3 (epistasis dominan-resesif) untuk A3 (Tabel 3). Nilai hasil uji Khi Kuadrat genotipe A1 adalah 0,89, lebih kecil dibandingkankan nilai $\chi^{2}$ tabel yaitu 5,99. Nilai $\chi^{2}$ Genotipe A3 adalah 0,55, lebih kecil dibandingkan dengan nilai $\chi^{2}$ tabel yaitu 3,84 .

Lain halnya dengan genotipe B1, umur anthesisnya mempunyai kesesuaian nisbah Mendel 3:1 (dominan sempurna), berbeda dengan nisbah Mendel karakter umur berbunganya 13:3. Meskipun nilai $\chi^{2}$ hitung nisbah Mendel 13:3 sama-sama lebih kecil dibandingkan $\chi^{2}$ tabel akan tetapi nilai nisbah Mendel 3:1 lebih kecil dibandingkan nilai nisbah Mendel 13:3, 2,2 < 2,96, maka nisbah Mendel 3:1 lebih sesuai dengan bentuk grafik umur anthesis. Nisbah Mendel dominan sempurna adalah ketika suatu suatu gen dominan menutup pengaruh alel resesifnya dengan sempurna (Karmana \& Rostini, 2008)

\section{SIMPULAN}

1. Sebaran data fenotip untuk karakter umur berbunga dan umur anthesis pada genotip A1, A3 dan B1 tidak menyebar normal atau diskontinu.

2. Pola pewarisan karakter umur berbunga dan umur anthesis pada genotipe A1, A3, dan B1 secara umum cenderung menyerupai pola segregasi nisbah Mendel 12:3:1 (dominan epstasis) dan 13:3 (epistasis dominan-resesif).

\section{DAFTAR PUSTAKA}

Allard RW. 1999. Principles of Plant Breeding Second Edition. John Wiley \& Sons, Inc. New York.

Anas and T Yoshida. 2004a. Genetic Diversity among Japanese Cultivated Sorghum Assessed with Simple Sequence Repeats Markers. Plant Prod. Sci. 7:217-223.

Anas and T Yoshida. 2004b. Heritability and Genetic Correlation of Al-torelance with Several Agronomic Characters in Sorghum Assessed by Hematoxylin Staining. Plant Prod. Sci. Vol. 7:280-282.

Baihaki, A. 2000. Teknik Rancangan dan Analisis Penelitian Pemuliaan. Universitas Padjadjaran : Bandung. $91 \mathrm{hlm}$
Crowder, LV. 1997. Genetika Tumbuhan (Diterjemahkan oleh Lilik Kurdiati dan Sutarso) Cetakan III. Gajah Mada University Press.Yogyakarta.

Food and Agriculture Organization. 2015. Sorghum bicolor (L.) Moench. Tersedia di http://www.fao.org/ag/agp/agpc/doc/gbase/d ata/pf000319.htm

Francis, DM, HL Merk and D Namuth-Covert. 2012. Gene pyramiding using molecular markers. Plant Breed. Genomics Available at http://www.extension.org/pages/32465/gene -pyramiding-using-molecularmarkers\#.VbIQp6RVikp (verified 24 July 2015).

Gelonch, GB, GJ Rebetzke, RA Richards, and I Romagosa. 2011. Genetic control of duration of pre-anthesis phases in wheat (Triticum aestivum L.) and relationships to leaf appearance,tillering, and dry matter accumulation. Journal of Experimental Botany 63(1): 69-89.

Gomez, KA dan AA Gomez. 1995. Statistical Procedures for Agriculture Research. An IRRI Book. John Wiley \& Sons. Sixth Edition. New York.

House, LR. 1985. A Guide to Sorghum Breeding. Second Edition. International Institute For the Semi-Arid Tropics (ICRISAT).

Karmana, HM dan N Rostini. 2008. Genetika Tumbuhan. Pustaka Giratuna. Bandung.

Komariah, A, A Baihaki, R Setiamihardja, dan S Djakasutami. 2003. Pola pewarisan aktivitas nitrat reduktase pada daun dan pada akar, serta kadar $\mathrm{N}$ total tanaman sebagai karakter penciri toleransi kedelai terhadap genangan. Zuriat 18 (1).

Murphy, R, RR Klein, DT Morishige, JA Brady, WL Rooneyd, FR Millere, DV Dugas, PE. Klein, and JE Mullet. 2011. Coincident Light and Clock Regulation Of Pseudoresponse Regulator Protein 37 (PRR37) Controls Photoperiodic Flowering in Sorghum. Department of Biochemistry and Biophysics, Texas A\&M University.

Nugroho, WP, M Barmawi, dan N Sa'diyah. 2013. Pola segregasi karakter agronomi tanaman kedelai (Glycine max [L.] Merrill) generasi $\mathrm{F}_{2}$ hasil persilangan Yellow Bean $\mathrm{x}$ Taichung. Jurnal Agrotek Tropika 1 (1): 205-214. 
Quinby, RJ. 1974. Sorghum Improvement and the Genetics of Growth. Texas A\&M University Press. Texas.

Rooney W, dan Aydin S. 1999. Genetic control of a photoperiod - sensitive response in Sorghum bicolor (L.) Moench. Crop Science 39: 397-400.

Sleper, DA and JM Poehlman. 2006. Breeding Field Crops Fourth Edition. Lowa State University Press. Ames.

Sa'diyah, N. S Ardiansyah, dan M Barmawi. 2013. Pola segregasi karakter agronomi tanaman kedelai (Glycine Max [L.] Merrill) generasi $\mathrm{F}_{2}$ hasil persilangan Wilis X Malang 2521. Prosiding Semirata FMIPA Universitas Lampung.
Salvi, S. S Castelletti, and R Tuberosa. 2010. An updated consensus map for flowering time QTLs in maize. Maydica 54 : 501-512.

Susanto, AH. 2011. Genetika. Graha Ilmu.Yogyakarta.

Trustinah. 1997. Pewarisan beberapa sifat kualitatif dan kuantitatif pada kacang tunggak (Vigna unguiculata (L) Walp). Balai Penelitian Pertanian Tanaman Pangan 15 (2) : 48-54.

Yano, M, S Kojima, Y Takahashi, $\mathrm{H}$ Lin, and $\mathrm{T}$ Sasaki. 2001. Genetic Control of Flowering Time in Rice, a Short-Day Plant. Department of Molecular Genetics, National Institute of Agrobiological Sciences, Tsukuba, Ibaraki 305-8602, Japan. 